\title{
Laczó, Ferenc (ed.). 2019. Confronting Devastation: Memoirs of Holocaust Survivors from Hungary. Toronto: Azrieli Series of Holocaust Survivor Memoirs, XI, 2019. 453 pp, ill.
}

\author{
Reviewed by Judith Szapor, McGill University
}

The Azrieli Foundation, endowed by the late Israeli-Canadian architect, developer, and philanthropist David Azrieli has played an important role in strengthening academic, scientific, and cultural ties between Israel and Canada, the two countries that its Holocaust survivor founder has come to call his homelands. While the academic programs operating generous graduate, postdoctoral, and faculty fellowships are based in Israel, the Foundation's other core activity has focused on-and has become a leader in-Holocaust education in Canada. The Foundation's Holocaust Survivor Memoirs Program was established in 2005 with a mission of collecting and publishing survivor testimonies. In contrast to similar and better-known, more comprehensive oral history collection projects, such as the Fortunoff Video Archive for Holocaust Testimonies and the Visual History Archive of the USC Shoah Foundation, the Azrieli program has been committed exclusively to the collection and publication of testimonies of Canadians: that is, of survivors who at some point came to Canada. So far, sixty-nine of these testimonies have been published in sixty-one tomes. Arranged into handsome box sets, the memoirs have been distributed free of charge to Canadian educational institutions and teachers, to serve as useful sources for Holocaust education at every level, from elementary schools to universities.

Confronting Devastation is only the second anthology of the Azrieli Series of Holocaust Survivor Memoirs, preceded by Before All Memory Is Lost: Women's Voices from the Holocaust, 2019, edited by Myrna Goldenberg, itself a welcome addition to the series, given the long overdue scholarly and public interest in women's experiences and accounts of the Holocaust. The occasion prompting the publication of Confronting Devastation was the recent seventy-fifth anniversary of the Holocaust in Hungary, the deportation in 1944 of over six hundred thousand Jews from the territory occupied by Hungarian and German forces. In this-to use the term of Götz Aly and Christian Gerlach in their eponymously titled book-"last chapter" of the Shoah, as a result of the deportation of the Jews from the countryside and their murder on an industrial scale at Auschwitz-Birkenau, as well as the death of the Jews of Budapest at the hand of Hungarian Fascists and of bombing, famine, and diseases, approximately five hundred and fifty thousand of Hungary's Jews were killed.

*judith.szapor@mcgill.ca

$($ (c) $)$ EY

ULIS D-Sorke
New articles in this journal are licensed under a Creative Commons Attribution 4.0 International License.

This journal is published by the University Library System of the University of Pittsburgh as part of its D-Scribe Digital Publishing Program and is cosponsored by the University of Pittsburgh Press 
Szapor, Judith. "Laczó, Ferenc (ed.). 2019. Confronting Devastation: Memoirs of Holocaust Survivors from

Hungary. Toronto: Azrieli Series of Holocaust Survivor Memoirs, XI, 2019. 453 pp, ill.

" Hungarian Cultural Studies. e-Journal of the American Hungarian Educators Association, Volume 13 (2020) DOI: 10.5195/ahea.2020.410

The volume draws on twenty-one previously unpublished testimonies, highlighting the invaluable role of the Azrieli Foundation's Holocaust Survivor Memoirs Program in preserving the memory and offering a rich and nuanced overview of survivor experiences. The editor of the volume, Ferenc Laczó, Assistant Professor of Maastricht University, is uniquely qualified for this ambitious task: he is the author of Hungarian Jews in the Age of Genocide: An Intellectual History, 1929-1948 (Leiden: Brill, 2016); and he is one of the editors of Ernő Munkácsi's recently translated (from Hungarian) How It Happened: Documenting the Tragedy of Hungarian Jewry (McGill Queen's UP, 2019), a crucial source for the history of the Holocaust in Hungary.

The five eloquently titled sections of the book are the following: "The Contradictions of Daily Life Under Worsening Exclusion: Experiences in Hungary Before 1944," "Drills and Humiliation: Jewish Men in Labour Battalions," "Horrors and Survival: In Ghettos and Camps," "Persecution and Escape in Budapest," and "The Sorrows of Liberation." Together, these thematic sections assign a chronological order to the excerpts from testimonies whose authors come from a wide range of socio-economic, cultural, and religious backgrounds, and who had experienced the Holocaust as young children, teenagers, or young adults divided almost evenly by gender. At the same time, the chronological and thematic lines along which the sections are organized illuminate the vast spectrum of experiences, determined by geographical and socioeconomic conditions, and at times tempered by audacity or sheer luck. Laczó outlines the historical context of these texts and problematizes their use as testimonies in a general Introduction. Then, for each section in the book, he offers an overview of its specific historical background in short, concise and accurate Forewords. In addition, footnotes and a glossary make the texts more accessible to a general readership. Finally, an illustrated set of short biographies, which, judging by the texts, may have been written by the survivors' relatives complete the volume.

An important question concerns the identity and identification of the survivors as both Jews "from Hungary" and, by virtue of their inclusion among the Azrieli testimonies, as Canadians. The first definition, "Jews from Hungary," has the advantage of conveniently bypassing the often-laborious binary of "Hungarian Jews" vs. "Jews of Hungary" and leaving the thorny problem of self-identity aside. But this definition leaves unaddressed the fact that some of the authors in the volume are "from" Hungary only in the vaguest sense, such as the PolishJewish refugee who escaped to Hungary in search of a (relatively) safe haven, or the Yiddishspeaking Jewish youth who became "from Hungary" overnight as a result of the Axis's decision of carving up and reassigning parts of Czechoslovakia and Transylvania to its allies. These transitions are clearly explained in the relevant section's Foreword, but it would have been interesting to learn more about the editorial decision to cast the net so wide.

The identification of the survivors as Canadians is - as we learn from the brief biographies included at the end of the volume - similarly vague, because only a few of them came directly to Canada, and some did so decades after the end of the war. And although one can be certain that the authors of the testimonies all cherished the chance to build a new life or join their children in Canada, perhaps this is the place to remind those not familiar with Canadian history that although today widely respected for its generous immigration policies, Canada's wartime attitude towards Jewish refugees was characterized by the consular instruction of "None is Too Many," which became the title of the celebrated study of Irving Abella and Harold Troper (None Is Too Many: Canada and The Jews of Europe, 1933-1948, Toronto: Lester \& Orpen Dennis, 1983, U of Toronto P, 2012). Given the Foundation's focus on Canadian survivors, the 
addition of a few more titles in the Introduction (such as: Erika Gottlieb, Becoming My Mother's Daughter: A Story of Survival and Renewal, 2008; Carolyn Gammon and Israel Unger, The Unwritten Diary of Israel Unger, 2014; Eva C. Karpinski, Borrowed Tongues: Life Writing, Migration, and Translation, 2012, all published by Wilfried Laurier UP), might have provided a sense of the keen Canadian scholarly interest in Holocaust testimonies, including the problems of translation of life writing by survivors. As well, and in addition to the comprehensive references to general studies on the Holocaust in the Introduction and the Forewords, a couple of specific studies (Rita Horváth, "Jews in Hungary after the Holocaust: The National Relief Committee for Deportees, 1945-1950," Journal of Israeli History 19.2, 1998: 69-91 on the Degob testimonies; Louise O. Vasvári, "Lefordított traumák, lefordított életek" ['Translated Traumas, Translated Lives'], Múlt és Jövö 1, 2009: 35-62; Éva Kovács, András Lénárt, and Anna Lujza Szász, "Oral History Collections on the Holocaust in Hungary," S.I.M.O.N. SHOAH: INTERVENTION. METHODS. DOCUMENTATION, Vol. 1 No. 2, 2014, 48-66) would have rounded out the bynecessity short historiographical overview.

The authors of the volume's testimonies could not be more different from the HungarianJewish writers whose wartime diaries and memoirs are considered by scholars and general readers the classics of the genre. Citing only those available in English, they include Ernő Szép, The Smell of Humans: A Memoir of the Holocaust in Hungary, transl. John Bátki, Introduction Dezső Tandori (Budapest and New York: Central European UP, 1994); Béla Zsolt, Nine Suitcases, transl. Ladislaus Löb (London: Jonathan Cape, 2004), and A Nation Adrift, The 19441945 Diaries of Miksa Fenyö, translated by Mario D. Fenyö (Saint Helena, CA: Helena History Press, 2018). For one, these works were published shortly after the war, and more importantly, they were written by some of the leading writers and intellectuals of Hungary. But far from being a deficit, this is exactly the quality that gives the collection of the Azrieli testimonies its vitality. Few of the authors in this volume would qualify (and most would have been too young to complete an education) as an intellectual and none of them as a writer. But they all offer a unique perspective, with some of them providing the tragically underrepresented voices of the Hungarian countryside's Orthodox Jewry. Others-those only passing through wartime Hungaryrepresent a rare outsider's perspective on the informal, hidden, secular, or religious networks of Budapest Jews in those fateful months. Read alongside the above cited, outstanding testimonies of high literary and cultural-historical value, the Azrieli anthology offers a valuable addition to the genre and, in accordance with the Azrieli Foundation's mission, a helpful source of Holocaust education. 